\title{
Developing and Application of Mobile Game Based Learning (M-GBL) for High School Students Performance in Chemistry
}

\author{
Ucu Cahyana \\ Universitas Negeri Jakarta, Jakarta, INDONESIA \\ Maria Paristiowati \\ Universitas Negeri Jakarta, Jakarta, INDONESIA \\ Dwi Amelia Savitri \\ Universitas Negeri Jakarta, Jakarta, INDONESIA \\ Siti Nuryana Hasyrin \\ Universitas Negeri Jakarta, Jakarta, INDONESIA
}

Received 22 March 2017 • Revised 22 August 2017 • Accepted 15 September 2017

\begin{abstract}
This study aims to develop and understand the effect of a mobile game based learning (MGBL) implementation on student learning outcomes associated with student learning independence. The research was conducted in three schools at 58 Jakarta High School, 77 Jakarta High School, and 78 Jakarta High School in the academic year 2016/2017. The research method used was quasi-experiment with two ways Anava research design (treatment by level 2x2). A total of 40 students, as a sample of the study, were selected using a simple random sampling technique. In the experimental class, the learning process used M-GBL media which has been validated by experts and tested against students and teachers. While students in the control class, the learning process used traditional media. The conclusions are: M-GBL media is feasible to be used as chemistry learning media which is practical, fun, interesting, can be used anywhere, and in accordance with facilities owned by learners. M-GBL media has a positive effect on students chemical learning outcomes when applied to groups of students who have high learning independence; in groups of students who have low learning independence, students' academic achievement when taught using M-GBL media were lower than students taught using traditional media owing to the factor of learning independence.
\end{abstract}

Keywords: mobile game based learning, learning outcomes, learning independence, chemistry

\section{INTRODUCTION}

Teaching and learning activities are effective when using media that is integrated with technology to help enhance students' understanding as well as their interest in the topic. Through the Internet, information technology is a way for the world to generate the multiplier effect of learning (Wu \& Tai, 2016). Technology is a complementary tool for enhancing innovative instructional models and, due to the prevalence of technology in our society, especially for students, many educators strive to make its integration into education a reality (Ekmekci \& Gulacar,2015). Game

(C) Authors. Terms and conditions of Creative Commons Attribution 4.0 International (CC BY 4.0) apply. Correspondence: Ucu Cahyana, Chemistry Education, Universitas Negeri Jakarta, Rawamangun Muka, Jakarta, Jakarta, Indonesia. 


\section{Contribution of this paper to the literature}

- The characteristics of the effective use of M-GBL media on student learning: the use of books replaced by RAM with learning that can be arranged and connected. Mobile games do not require many pages of books and can be incorporated into the handset so they can be carried easily. Learning is designed for use on mobile devices. Mobile games can be used on any mobile phone provided that the appropriate operating system base is installed. M-GBL media can be learned anywhere, any time by the students to enable them to obtain and explore the subject matter more effectively.

- The results of the effectiveness test of using M-GBL media in chemistry learning. The using of M-GBL media will have a positive effect on students' chemical learning outcomes when applied to groups of students who have high learning independence. In groups of students who have low learning independence, the use of M-GBL media is lower than that of students taught using traditional media.

based learning, on mobile devices, is an alternative learning media being developed by researchers to create fun learning that is easy to understand and accessible to students.

Learning on mobile devices leads to the use of mobile phones as a learning media. Learning based on mobile devices (mobile game based learning) is an alternative learning service which can be implemented anywhere and anytime (Darmawan, 2012). Mobile game based learning is a game that contains a summary of the lesson topic, is constructed by different levels of education, is adjusted to the prevailing curriculum and is able to run on mobile devices. Because electronic games play such a prominent role in young people's lives, researchers and educators, hope to combine the intrinsic motivation that students show towards electronic games that contain a summary of the topic of the lesson and objectives, to make learning more fun and enjoyable (Marina Papastergiou, 2009a).

M-GBL has now become a new trend in education as most mobile devices, especially smartphones and tablets, can run user-friendly mobile applications. Mobile games based learning developed for chemical materials, among other uses, is the application OCRA (Organic Chemistry Reaction Application) being developed by Talib (2014). In OCRA, the users can explicitly form and break the chemical bond between atoms. Users can use the touch screen feature to explicitly demonstrate the organic reaction mechanism, explicitly through an electron moving technique, which is used to conceptually visualize the mechanistic steps in the organic reaction mechanism. A Multimedia Based maze game integrated with a scientific approach being developed by Setiawan (2016) has enhanced student learning outcomes. Based on this study, the scientific approach to learning by using a multimedia based labyrinth game can improve the quality of learning and increase student understanding. The examples provided here are practical examples where a mobile application has been innovatively designed to enhance the value of e-learning in an educational context. However, there is a need to develop more learning tools that specifically optimize the use of mobile applications to include other chemistry topics.

Mobile games based learning, in the form of a quiz which contains a summary of the material and practice questions for chemistry material, is operated with the help of a mobile phone that has an Android operating system. Chemistry material presented as a mobile game will make students more interested and facilitate their understanding of the description of a chemical reaction. Gaming activities are a good source of engagement and bring fun into learning by providing an instant appraisal for players when tasks are completed successful, thereby motivating them to reach higher stages in the gameplay (Mathrani, Christian \& Ponder-Sutton, 2016). Problembased learning, contained in the game on mobile devices, uses various ways to help students understand concepts and resolve various issues. Some researchers believe that teaching materials and techniques are not as good as having children learn via games by having fun and being happy (Norman, 1981). Games are easily accepted and used by students (Kafai, 1995). Furthermore, games can help students develop problem-solving skills (Seonju, 2002; Chuang \& Chen, 2009; Lee \& Chen, 2009; Blumberg, Rosenthal, \& Randall, 2008; Shih, Shih, Shih, Su, \& Chuang, 2010). Media M-GBL is presented as an alternative to help students understand chemistry by using games on mobile devices. 
Table 1. Two Ways Anova Research Design (Treatment by Level 2x2)

\begin{tabular}{lcc}
\hline \multirow{2}{*}{ Learning Independence (B) } & \multicolumn{2}{c}{ Media learning (A) } \\
\cline { 2 - 3 } & $\begin{array}{c}\text { Mobile game based learning } \\
(\mathbf{M}-\mathbf{G B})\left(\mathbf{A}_{\mathbf{1}}\right)\end{array}$ & Traditional Media $\left(\mathbf{A}_{\mathbf{2}}\right)$ \\
\hline Higher Learning Independence $\left(\mathrm{B}_{1}\right)$ & $\mathrm{A}_{1} \mathrm{~B}_{1}$ & $\mathrm{~A}_{2} \mathrm{~B}_{1}$ \\
\hline Low Learning Independence $\left(B_{2}\right)$ & $\mathrm{A}_{1} \mathrm{~B}_{2}$ & $\mathrm{~A}_{2} \mathrm{~B}_{2}$ \\
\hline
\end{tabular}

The use of M-GBL media in learning relates to students' learning independence. Student learning independence is one of the internal factors in a person that will lead to a sense of responsibility and confidence to achieve. Learning independence is very important for students to have because with this attitude students can discipline themselves to be responsible for the learning process. The learning environment with M-GBL media provides a means by which students can manage their learning (Chen, 2008).

\section{METHODOLOGY}

The research was conducted in three schools during the 2016/2017 academic year at: 58 Jakarta High School, 77 Jakarta High School, and 78 Jakarta High School. A quasi experimental method was used with Two-Way Anova research design (treatment by level 2x2). Two-Way Anova research design (treatment by level $2 \times 2$ ) in this study can be seen in Table 1.

The sample in this study, consisting of 40 students from class $\mathrm{X}$, was taken using a simple random sampling technique. Students in the study used M-GBL media that has been validated by experts and has been tested by students and teachers. The students in the control class used traditional media in the learning process. Data collection was is done using a test technique and questionnaire, that is, a learning results test and a self-study learning questionnaire. The test used approximately 20 multiple choice items with 5 choices. The multiple-choice test of validity was calculated using the "biserial point" analysis technique, while the reality was calculated using Kuder Richardson-20 (KR-20). In the test, the validity description was calculated using Karl Pearson's "correlational product moment" analysis technique, while the reality was calculated using Alpha Cronbach. The type of selflearning instrument used was a questionnaire in the form of statements totaling 28 items which calculated the validity using Karl Pearson's “correlational product moment" analysis technique, while the realities was calculated using Alpha Cronbach.

Before being analyzed, the student's score was tested for normality and homogeneity. In this study, a normality test was done using the Liliefors test, while homogeneity test was done using the Fisher test and Bartlett Test. There are four hypotheses tested in this study. The first hypothesis (main effect) and the second (interaction effect) were tested using techniques of analysis of variance (ANOVA) two ways, while the third and fourth hypothesis (simple effect) were tested using the Tukey test.

\section{RESULTS AND DISCUSSION}

The product of mobile game based learning (M-GBL) development on reaction rate material is validated by media experts, chemistry concepts experts, and linguists. Furthermore, trials were conducted with students and teachers. Reaction rate materials are presented in the form of books, websites, slides or handouts. The effectiveness of M-GBL media was tested using the Two-Ways ANOVA test (treatment by level 2x2).

\section{The Evaluation Product M-GBL Media by Validation Expert}

Validation of the test stage aims to take into account the judgments, criticisms, and suggestions from experts on M-GBL media so as to developed and produce media of good quality. Expert validation testing stage has been done by material and language experts as well as by media experts. 
Table 2. Results of media M-GBL Assessment by content experts and linguists

\begin{tabular}{lccc}
\hline Aspects & $\begin{array}{c}\text { Question Number } \\
\text { Item }\end{array}$ & $\begin{array}{c}\text { Average Feasibility } \\
\text { Percentage }\end{array}$ & Criteria \\
\hline $\begin{array}{l}\text { The relevance of content substance to the } \\
\text { competencies that must be achieved by students }\end{array}$ & 1,2 and 3 & $86 \%$ & Very good \\
\hline Problem and Discussion & $4,5,6,7,8,9$ and 10 & $90 \%$ & Very good \\
\hline Language & 11 and 12 & $83 \%$ & Very good \\
\hline Average Overall Media Assessment & & $86 \%$ & Very good \\
\hline
\end{tabular}

Table 3. Results of M-GBL Assessment from media expert

\begin{tabular}{lccc}
\hline Aspects & $\begin{array}{c}\text { Question Number } \\
\text { Item }\end{array}$ & $\begin{array}{c}\text { Average Feasibility } \\
\text { Percentage }\end{array}$ & Criteria \\
\hline Audio and Visual Display & $\begin{array}{c}1,2,3,4,5,6,7,8, \\
\text { and } 9\end{array}$ & $82 \%$ & Very good \\
\hline Software implementation and engineering & $10,11,12$, and 13 & $98 \%$ & Very good \\
\hline Average Overall Media Assessment & & $90 \%$ & Very good \\
\hline
\end{tabular}

\section{Validation test by expert on chemistry concepts and language}

Six lecturers as experts on chemistry concepts and language. The feasibility test instrument, given to by the material and language experts, consisted of 12 questions covering several aspects, namely the relevance of the content to the competencies to be achieved by students; questions and discussion; and the language used in the media.

Based on Table 1, the average feasibility assessment of M-GBL media by content experts, and linguists as a whole, is $86 \%$ with very good criteria. Also, based on the calculation of reliability between rater, it can be seen that the reliability value obtained for 0.67 with good criteria. These results indicate that the instrument used is reliable, and the quality of M-GBL media material is good. Information obtained from material and linguistic instruments is known that M-GBL media has met the criteria of quality media regarding validity, accuracy, conformity, and coverage proposed by Elissavet and Economides (2000).

\section{Validation test by media experts}

The validation test by media experts aims to know the feasibility of M-GBL media developed. The feasibility test phase by the media experts in this research involved six respondents, four of which are media learning design experts, and two IT experts. The instruments used by the media experts consisted of 13 questions covering visual display aspects as well as software implementation and engineering.

Table 3 shows that the average of the overall M-GBL media assessment result is $90 \%$ with very good criteria. Also, based on the results of the assessment using reliability between rater, it can be seen that the results obtained reliability value of 0.62 with good criteria. These results indicate that the instrument used is reliable, feasible to use, and the quality of M-GBL media is good. Based on the information obtained from the results of the instrument and the test of reality, it can be concluded that the resulting learning media meets the technical quality criteria proposed by Walker and Hess (Arsyad, 2011).

\section{The Evaluation Product M-GBL Media by Trial Test on Students and Teachers}

\section{Results of product testing by student in small group}

In the trials, undertaken by by a small group of students, participants were given an application to install on their mobile phone using data transfer. The trial was conducted by distributing questionnaires to 20 students in 
Table 4. Assessment test of M-GBL as learning media by a small group of students

\begin{tabular}{lccc}
\hline Aspects & Question Number Item & $\begin{array}{c}\text { Average Feasibility } \\
\text { Percentage }\end{array}$ & Criteria \\
\hline Questions and discussion & $1,2,3,4$ and 5 & $76 \%$ & Good \\
\hline Language & 6 and 7 & $77 \%$ & Good \\
\hline Audio and Visual Display & $8,9,10,11,12,13,14$, and 15 & $78 \%$ & Good \\
\hline Software Implementation and Engineering & $16,17,18,19$ and 20 & $76 \%$ & Good \\
\hline Benefits & $21,22,23$, and 24 & $83 \%$ & Very Good \\
\hline Average Overall Media Assessment & & $78 \%$ & Good \\
\hline
\end{tabular}

the second grade of high school in Jakarta. The instrument used for these media trials consisted of a 26 item of questionaire covering several aspects as stated in Table 4. This small-scaled student test phase aimed to find out what the students' assessment of the developed M-GBL media was, as well as to hear the criticism and suggestions from the students for improve the media so that it could inform the larger scale study. In the experiments conducted by students on the media produced, problems were identified and discussion points raised, such as, language used, audio and visual appearance, and software implementation and engineering and expediency. Here is a table of student test results on a small scale:

Table 4 shows that in the aspect of expenditure, the highest percentage of average feasibility is highest compared to another aspect that is $83 \%$ with very good criteria. The indicator of this aspect of expediency concerns students' interest in chemistry after using M-GBL media. Two questions cover the reasons for learning using the game being more interesting and fun and the interest of students wanting to learn chemistry further after using $\mathrm{M}$ GBL media. Based on the instruments distributed to 20 students, $85 \%$ of them stated that learning by using M-GBL media is more interesting and fun, and $90 \%$ of students were interested in studying chemistry further after using M-GBL media. Some students commented on the use of M-GBL media, one of which stateed that rather than using a mobile phone for game play, it would be better to try the M-GBL media as it is easy to operate.

Based on the results of the small-scale use of M-GBL media assessment by students, it can be claimed that the M-GBL media is well made and acceptable to the students. This is indicated by the average result of the overall media assessment that has an assessment percentage of $78 \%$ with good criteria. The suggestions from students about the media, namely, the use of a background that is too crowded and the addition of music. These suggestions were used to improve the media for subsequent large-scale trials.

\section{Results of product testing by students in large group}

After trialing the media with the small-scale student group and improving the media, the next phase of the research was to conduct media large-scale trials. This stage was done by distributing questionnaires to 100 students in the second grade of high school in Jakarta. The medium test instrument used was the same as the questionnaire used for the small-scale trial; 26 questions consisting of several aspects in Table 5. The large-scale student trial stage aimed to reveal the students' assessment of mobile learning media developed after the smallscale trial and following the improvements made. Below is a table of results of meditation of the large-scale trials. 
Table 5. Results of M-GBL Media Trial Assays by Students of Large Scale

\begin{tabular}{lccr}
\hline Aspects & Question Number Item & $\begin{array}{c}\text { Average Feasibility } \\
\text { Percentage }\end{array}$ & Criteria \\
\hline Questions and discussion & $1,2,3,4$ and 5 & $86 \%$ & Very Good \\
\hline Language & 6 and 7 & $81 \%$ & Very Good \\
\hline Audio and Visual Display & $8,9,10,11,12,13,14$, and 15 & $81 \%$ & Very Good \\
\hline Software Implementation and Engineering & $16,17,18,19$ and 20 & $84 \%$ & Very Good \\
\hline Benefits & $21,22,23$, and 24 & $91 \%$ & Very Good \\
\hline Average Overall Media Assessment & & $85 \%$ & Very Good \\
\hline
\end{tabular}

Table 6. Trial Results of M-GBL Media by Teacher

\begin{tabular}{lccc}
\hline Aspects & $\begin{array}{c}\text { Question } \\
\text { Number Item }\end{array}$ & $\begin{array}{c}\text { Average Feasibility } \\
\text { Percentage }\end{array}$ & Criteria \\
\hline $\begin{array}{l}\text { The relevance of content substance to the competencies } \\
\text { that must be achieved by students }\end{array}$ & 1 and 2 & $100 \%$ & Very Good \\
\hline Questions and discussion & $3,4,5,6$ and 7 & $88 \%$ & Very Good \\
\hline Language & 8 and 9 & $88 \%$ & Very Good \\
\hline Audio and Visual Display & $10,11,12,13,14$, & $89 \%$ & Very Good \\
\hline Software Implementation and Engineering & $15,16,17$ and 18 & $88 \%$ & Very Good \\
\hline Benefits & $19,20,21$ and 22 & $100 \%$ & Very Good \\
\hline Average Overall Media Assessment & 23 & $91 \%$ & Very Good \\
\hline
\end{tabular}

Based on the results of M-GBL medium-scale \& large-scale trial assessments, all aspects of the assessment increased compared to the M-GBL media outcome assessment results by the small-scale trial asessment, where the average overall media outcome assessment on the large-scale trial asessment has a percentage Assessment of $85 \%$ with very good criteria. This indicates that the M-GBL media is a feasible tool to be used as an alternative learning medium with high school students in the year 11 chemistry classrooms in the concept of Rate Reaction. Presentation of material in the form of mobile learning media that has not been so developed cause the material presented more interesting than in other forms. Another reason that makes students interested in M-GBL media is that the developed M-GBL media is made using an off / on form so it can be used anywhere and anytime without any time constraints, even if there is no internet connection.

\section{Results of product testing by teachers}

The media was tested by giving the application to 10 chemistry teachers to be installed on their owned mobile phone by using data transfer. The instrument for teacher media trials consisted of 23 questions consisting of several aspects as stated in Table 6 . The following is a table of media test results by teachers:

Based on the results of the teacher media trials, as collated in the table above, it can be seen that the average assessment of M-GBL media, as a whole, is $91 \%$ with very good criteria. Based on the results of the media trials by teachers it can be said that the resulting M-GBL media is feasible to be used as an alternative tool for learning chemistry.

The M-GBL media product has advantages over other learning media, such as, the process of installing the media is very easy; the operation of the media is very easy, like operating a mobile phone in general; the medium can be used repeatedly without the need to use the internet, making it more economical; the material presented consists of several sub-items that are easy to understand; how to operate "touch and scroll" makes the display more interesting and simple; media can be operated anywhere and anytime according to the needs of learners; 
Table 7. Hypothesis Testing Results Using Two Ways Anova

\begin{tabular}{lcccccc}
\hline Variants & $\begin{array}{c}\text { Degree of } \\
\text { Freedom } \\
(\mathbf{D b})\end{array}$ & $\begin{array}{c}\text { The sum of } \\
\text { squares } \\
(\mathbf{J K})\end{array}$ & $\begin{array}{c}\text { Average } \\
\text { Number of } \\
\text { Squares } \\
\text { (RJK) }\end{array}$ & $\mathbf{F}_{\text {count }}$ & $\begin{array}{c}\mathbf{F}_{\text {table }} \\
(\boldsymbol{\alpha}=\mathbf{0 . 0 5 )}\end{array}$ & Conclusion \\
\hline Between $\mathrm{A}_{1}$ and $\mathrm{A}_{2}$ & 1 & 336.40 & 336.40 & 13.20 & 4.10 & $\mathrm{H}_{0}$ rejected \\
\hline Interaction $\mathrm{A} \times \mathrm{B}$ & 1 & 1742.40 & 1742.40 & 68.34 & 4.10 & $\mathrm{H}_{0}$ rejected \\
\hline In Group & 36 & 917.80 & 25.49 & - & & \\
\hline Total $(\mathrm{T})$ & 40 & 245624.00 & - & - & & \\
\hline
\end{tabular}

media can be used as a learning medium for learners in high school; problems can be contained in the quiz accompanied by discussion; the sequence of questions in the quiz menu is randomly created each time the quiz menu opens so learners cannot memorize quiz answers.

\section{The Application of M-GBL Media on Student Learning}

The application of M-GBL media in the study of chemistry learning, studying the effect of M-GBL media used on students' learning outcomes is related to learner independence. In this study, four hypotheses were tested.

\section{The effect of M-GBL media on student learning outcomes}

Based on the result of hypothesis testing (Table 7), the value of Fcount $(\mathrm{Fc})$ is 13.20. Meanwhile, the Ftable value at the level of significance $(\alpha)=0.05$ of 4.10 . Therefore, the value Fcount> Ftable, then $\mathrm{H}_{0}$ is rejected so it can be concluded that student learning outcomes, taught by using M-GBL media, are higher than students taught by using traditional media. Research can provide such results because, in the medium of mobile, game based learning, (M-GBL) has an advantage, that is, the use of books is replaced with RAM. Mobile games can readily incorporate content into the handset so they can be carried easily; learning is designed for use on mobile devices. Mobile games can be used on any mobile phone provided that the appropriate operating system is installed; and M-GBL media can be learned anywhere at any time by students enabling them to obtain and explore the subject matter more easily. Research conducted by Hwang et. al. (2013), suggests that mobile learning media is very promising in improving student achievement and student interest. Jabbour (2013) concurs that the use of mobile learning has a positive effect on student performance. It also affects the interaction between students and teachers in the learning process and has the impact of learning becoming more active. Based on the research, it is considered that students taught by using mobile learning media can learn independently anytime and anywhere to increase their knowledge. Thus, in this way the use of mobile games can impact on the high student's learning outcomes as they develop a deeper understanding of the subject matter. As proposed by Tømte and Olsen (2013), technology contributes to the increase in student learning outcomes in higher education.

In the study with students taught by using traditional media, the subject matter was delivered, in the classroom, by direct instruction using PowerPoint media. The students recorded the subject matter delivered by the teacher, causing the students to be dependent on the teacher and less independent. Based on this explanation, learning using traditional media becomes less effective because it is controlled by the teacher delivering the learning material rather than involving the students in in-depth learning activities.

\section{Interaction between M-GBL Media (A) and Learning Independence (B) on student learning outcomes}

Based on the hypothesis test result (Table 7), obtained value of Fcount ( $\mathrm{Fc}$ ) equal to 68.34. Meanwhile, the Ftable value at the level of significance $(\alpha)=0.05$ of 4.10 . Therefore, the value of Fcount $>$ Ftable, then $\mathrm{H}_{0}$ is rejected so it can be concluded that there is an interaction effect between learning media and learning independence of student learning outcomes. In this case, the media learning in question is M-GBL media and traditional media. The existence of interaction proves that each of media learning has a different influence on student learning outcomes 


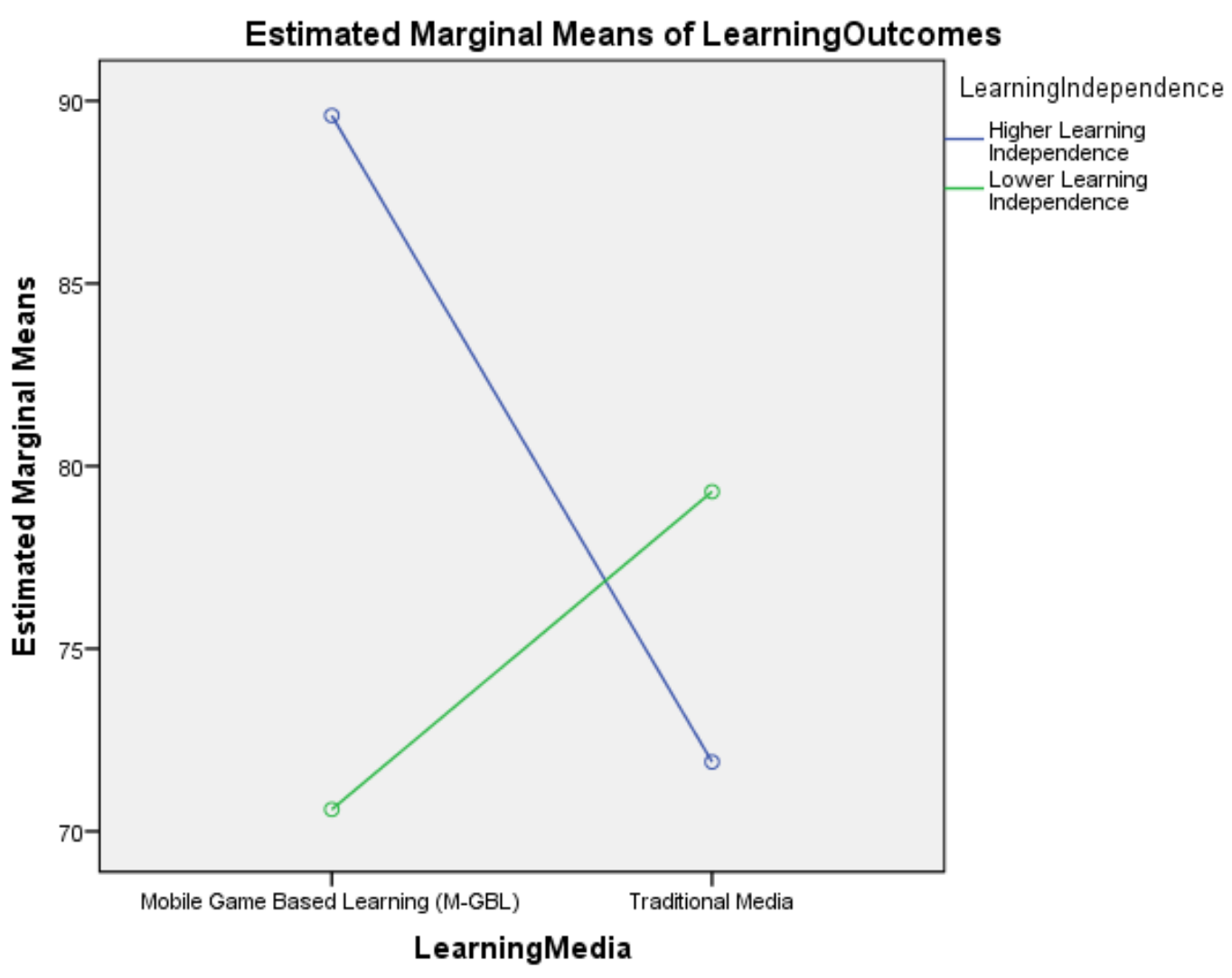

Figure 1. Graph Influence Interaction between Learning Media and Learning Independence of Student Learning Outcomes

if used with a group of students having different degrees of learning independence. The results show that M-GBL media is more effective if used with students who have high learning independence. Meanwhile, traditional media is more effective if used with students who have low learning independence. The influence of interaction between independent variables (learning media and learning independence) to the dependent variable (learning result) can be seen in Figure 1.

To improve student learning outcomes, by encouraging students to be independent learners, requires students who support a learning process that is fully optimized. The students' learning independence is essential so that they become responsible for the learning process. Implementation of independent learner attributes is demonstrated in the learning process where students do not only rely on books or teacher explanations as the main learning resources but they also engage in a mutual learning process. Based on the description above, it can be concluded there is an interaction between learning media and learning independence on student learning outcomes.

\section{Differences in student learning outcomes between groups $A_{1} B_{1}$ and $A_{2} B_{1}$}

Based on the result of hypothesis testing (Table 8), the value of $Q_{\text {count }}$ is 11.90 . Meanwhile, the value of $\mathrm{Q}_{\text {table }}$ at the level of significance $(\alpha)=0.05$ of 4.33 . Therefore, the value of $Q_{\text {count }}>Q_{\text {table, }}$ then $H_{0}$ is rejected so that it can be concluded that student learning outcomes taught by using mobile game based learning (M-GBL) are higher than students taught by using traditional media in groups of students who have high learning independence. The 
Table 8. Hypothesis Testing Results Using Tukey Test

\begin{tabular}{cccc}
\hline Groups & Qcount $_{\text {con }}$ & Q $_{\text {table }}$ & Conclusion \\
\hline $\mathrm{A}_{1} \mathrm{~B}_{1} \& \mathrm{~A}_{2} \mathrm{~B}_{1}$ & 11.90 & 4.33 & $\mathrm{H}_{0}$ rejected \\
\hline $\mathrm{A}_{1} \mathrm{~B}_{2} \& \mathrm{~A}_{2} \mathrm{~B}_{2}$ & 4.63 & 4.33 & $\mathrm{H}_{0}$ rejected \\
\hline
\end{tabular}

results also show that mobile media based learning (M-GBL) is more effective than traditional media, if used with groups of students who have high learning independence.

A person who is an independent learner often prefers to work alone, determine and choose how to work by his conscience. He attaches importance to autonomy in acting, decision making, and in the selection of activities in achieving goals. Learner independence is linked to the media used in the learning process by the main characteristics of M-GBL media that can be studied anywhere, anytime and by anyone who can help students to learn independently. Students who have to learn independence point out that the use of M-GBL media is more helpful and beneficial in acquiring the subject matter. Liu (2014) concludes that the use of e-learning media affects student independence and motivation in a way that increases student academic achievement.

\section{Differences in student learning outcomes between groups $A_{1} B_{2}$ and $A_{2} B_{2}$}

Based on the result of hypothesis testing (Table 8), obtained the $\mathrm{Q}_{\text {count }}$ value of 4.63. Meanwhile, the value of Qtabel at the level of significance $(\alpha)=0.05$ of 4.33 . Therefore, the value of $Q_{\text {count }}>Q_{\text {table, }}$ then $H_{0}$ is rejected so that it can be concluded that the results of student learning, taught by using M-GBL media, are lower than students taught by using traditional media in groups of students who have low learning independence. The results also show that traditional media are more effective than M-GBL media if used with groups of students who have low learning independence. Broadbant and Poon (2015) support this claim that one-way-based learning, using mobile media, can improve learning independence, time management, and critical thinking that can all have a positive impact on student learning outcomes.

Students who have low learning independence tends to become passive learners who follow the learning process as it is delivered so students who have this attitude may find it easier to master lessons than the students who do not have learner independence. The learning materials are structured and systematically delivered by the teacher. The process of learning with traditional media (PowerPoint) appears to be more advantageous for students who have low learner independence. Therefore, using M-GBL media with students who have low learner independence is not recommended due to the low motivation.

\section{CONCLUSION}

Based on the results of the research, it can be concluded that the test results validation by experts and the testing of students and teachers, M-GBL media has very good overall criteria. Thus that M-GBL media, developed in this research, is a feasible media to be used for learning chemistry that is practical, fun, interesting, can be used anywhere, and in accordance with the facilities owned by learners.

In the process of learning chemistry, the use of M-GBL media has a positive effect in improving student performance, in this case, improving student learning outcomes. Students are not bound by time and space. They can learn not only in the classroom but they can also study outside the classroom depending on the student's individual conditions. The learning material contained in M-GBL is interesting as it comes with games, animations, and learning videos.

The use of M-GBL media in the learning process must pay attention to indicator of student learning independence. Based on the results obtained, the use of M-GBL media will have a positive effect on student learning outcomes, when applied to groups of students who have high learning independence. By contrast, in groups of students with low learning independence, student learning outcomes, taught using M-GBL media, were lower than those taught using traditional media. 


\section{ACKNOWLEDGEMENT}

This research report was made possible through funding received from the Directorate Research Ministry of Research, Technology, and Higher Education. The authors would like to thank colleagues, Research Institution and Department of Chemistry Education Universitas Negeri Jakarta.

\section{REFERENCES}

Alaba, S. D., Ayobami, A. S., \& Lateef, A. R. (2015). The effectiveness of Mobile Learning as Disruptive and Innovative Strategy for Enhancing Quality Education at the University Level in Nigeria. Journal of Educational and Social Research, 5(1), 55 - 64.

Alkhezzi, F., \& Al-Dousari, W. (2016). The Impact of Mobile Learning on ESP Learners' Performance. The Journal of Educators Onway, 13(2), 73 - 101.

Alrasheedi, M., Capretz, L. F., \& Raza, A. (2015). A Systematic Review of the Critical Factors for Success of Mobile Learning in Higher Education (University Students' Perspective). Journal of Educational Computing Research, 52(2), $257-276$.

Al-Said, K. M. (2015). Students' Perceptions of Edmodo and Mobile Learning and Their Real Barriers towards Them. The Turkish Onway Journal of Educational Technology, 14(2), 167 - 180.

Barhoumi, C. (2015). The Effectiveness of WhatsApp Mobile Learning Activities Guided by Activity Theory on Students' Knowledge Management. Contemporary Educational Technology, 6(3), 221 - 238.

Broadbent, J., \& dan Poon, W. L. (2015). Self-Regulated Learning Strategies \& Academic Achievement in onway Higher Education Learning Environments: A systematic Review Internet and Higher Education: Elsevier, 27, 1-13.

Brown, T. H., \& Mbati, L. S. (2015). Mobile Learning: Moving Past the Myths and Embracing the Opportunities. International Review of Research in Open and Distributed Learning, 16(2), 115 - 135.

Chai, C. S., Wong, L. H., \& King, R. B. (2016). Surveying and Modeling Students' Motivation and Learning Strategies for Mobile-Assisted Seamless Chinese Language Learning. Educational Technology \& Society, 19(3), 170-180.

Chen, C., Yeh, T., \& Chang, C. (2016). The Effects of Game-Based Learning and Anticipation of a Test on the Learning Outcomes of 10th Grade Geology Students Eurasia Journal of Mathematics, Science E Technology Education, 12(5), 1379-1388. doi:10.12973/eurasia.2016.1519

Chen, W., Tan, N. Y. L., Looi, C.-K., Zhang, B., \& Seow, P. S. K. (2008). Handheld Computers as Cognitive Tools: Technology Enhanced Environmental learning. Research \& Practice in Technology Enhanced Learning, 3, 231252.

Dorji, U., Panjaburee, P., \& Srisawasdi, N. (2015). A Learning Cycle Approach to Developing Educational Computer Game for Improving Students' Learning and Awareness in Electric Energy Consumption and Conservation. Educational Technology \& Society, 18(1), 91-105.

Elissavet, G., \& Economides, A. A. (2000). Evaluation Factors of Educational Software (Onway). Proceedings International Workshop on Advanced Learning Technologies (IWALT). California: IEEE has 113-120.

Huang, C. S. J., Yang, S. J. H., Chiang, T. H. C., \& Su, A. Y. S. (2016). Effects of Situated Mobile Learning Approach on Learning Motivation and Performance of EFL Students. Educational Technology \& Society, 19(1), 263-276.

Hwang G. J., Wu, P. H., Zhuang, Y. Y., \& Huang, Y. M. (2013). Effects of the Inquiry-Based Mobile Game Based Learning. Model on The Cognitive Load and Learning Achievement of Student, Interactive Learning Environments, Routledge, 21(4), 338-354.

Jabbour, K. K. (2013). An Analysis of the Effect of Mobile game based learning (M-GBL) On Lebanese Higher Education. Bulgarian Journal of Science and Education Policy, 7(2), 280-301.

Khaddage, F., Müller, W., \& Flintoff, K. (2016). Advancing Mobile Learning in Formal And Informal Settings via Mobile App Technology: Where to From Here, and How? Educational Technology \& Society, 19(3), 16-26.

Kim, S.-H., Park, N.-H., \& Joo, K.-H. (2014). Effect of Flipped Classroom Based on Smart Learning on Self Directed and Collaborative Learning. International Journal of Control And Automation, 7(12), 68-90. 
Kumar, S. (2013). E- and M-Learning: A Comparative Study. International Journal on New Trends in Education and Their Implications, 4(3), 65 - 78.

Kurniawati, A. (2010). Studi Analisis Tools Pembelajaran Berbasis Game dalam Upaya Peningkatan Kompetensi Keahlian Pemrograman. Jurnal Rekayasa, 3(1), 51-66.

Mathrani, A., Christian, S., \& Ponder-Sutton, A. (2016). PlayIT: Game Based Learning Approach for Teaching Programming Concepts. Educational Technology \& Society, 19(2), 5 -17.

Nalliveettil, G. M., \& Alenazi, T. H. K. (2016). The Impact of Mobile Phones on English Language Learning: Perceptions of EFL Undergraduates. Journal of Language Teaching and Research, 7(2), 264 - 272.

Nouri, J., Pargman, T. C., Rossitto, C., \& Ramberg, R. (2014). Learning with or without Mobile Devices? A Comparison of Traditional School field Trips and Inquiry-Based Mobile Learning Activities. Research and Practice in Technology Enhanced Learning, 9(2), 241 - 262.

Powell, C. B., \& Mason, D. S. (2013). Effectiveness of Podcasts Delivered on Mobile Devices as a Support for Student Learning during General Chemistry Laboratories. Journal of Science and Education Technology, 22, 148 - 170.

Prensky, M. (2001). Digital Game-Based Learning. New York, NY: McGraw Hill.

Quinn, C. (2000). m-Learning. Mobile, Wireless, In-Your-Pocket Learning. http://www.wayzine.com/2.1/features/cqmmwiyp.htm.(diakses pada tanggal 26 November 2016)

Safaat, N. (2011). Pemrograman Aplikasi Mobile Smartphone dan Tablet PC Berbasis Android. Bandung: Informatika.

Setiawan, W., Hafitriani, S., \& Prabawa, H. (2016).The scientific learning approach using multimedia-based maze game to improve learning outcomes. http://dx.doi.org/10.1063/1.4941162

Shih, J.-L., Chuang, C.-W., \& Hwang, G.-J. (2010). An Inquiry-based Mobile Learning Approach to Enhancing Social Science Learning Effectiveness. Educational Technology \& Society, 13(4), 50-62.

Shin, W. S., \& Kang, M. S. (2015). The Use of Mobile Learning Management System at an Onway University and Its Effect on Learning Satisfaction and Achievement. International Review of Research in Open and Distributed Learning, 16(3), 110 - 130.

Song, Y. (2013). Developing a Framework for Examining the "Niche" for Mobile-Assisted Seamless Learning from an Ecological Perspective. British Journal of Educational Technology, 44(5), 167 - 170.

Talib, O., Othman, A., \& Shariman, T. P. N. T. (2014). OCRA - Authentic mobile application for enhancing the value of mobile learning in organic chemistry. In Proceedings of the European Conference on e-Learning. Academic Conferences Limited, 527-535.

Thomas, K., \& Munoz, M. A. (2016). Hold the Phone! High School Students' Perceptions of Mobile Phone Integration in the Classroom. American Secondary Education, 44(3), 19 - 37.

Tømte, C., Kårstein, A., \& Olsen, D. S. (2013). IKT i lærerutdan-ningen. På vei mot profesjonsfaglig digital kompetanse? [ICT in teacher education. Moving towards a professional digital compe-tence? ]. Oslo: Nordic Institute for Studies in Innovation, Research and Education.

Winarno, Edy. (2011). Membuat Sendiri Aplikasi Android untuk Pemula. Jakarta: PT Elex Media Komputindo.

Wong, A. (2016). Student Perception on a Student Response System Formed by Combining Mobile Phone and a Polling Website. International Journal of Education and Development using Information and Communication Technology, 2(1), 144 - 153.

Wu, W. C., \& Perng, Y. H. (2016). Research on the Correlations among Mobile Learning Perception, Study Habits, and Continuous Learning. Eurasia Journal of Mathematics, Science E Technology Education, 12(6), 1665 - 1673.

\section{http://www.ejmste.com}

